\footnotetext{
http://www.bbc.com/capital/story/20190220-how-can-adistracted-generation-learnanything. (дата звернення: 25.06.2020).

6. Taylor J. Raising Generation Tech: Preparing Your Children for a MediaFueled World. URL: https://itunes.apple.com/us/book/raising-generation-tech/id 709662385?mt=11. (дата звернення: 25.06.2020).

\section{REFERENCES} School]

1. Vypusknyk Novoi Shkoly [A graduate of the New

2. Hutevich, V.A. (2017) Tekhnolohiia mediaosvity $v$ navchanni molodshykh shkoliariv [Technology of media education in teaching junior high school students]

3. Yelnikova, O.V. (2001) Interaktyvni metody navchannia, yikh mistse u klasyfikatsii pedahohichnykh innovatsii [Interactive teaching methods, their place in the classification of pedagogical innovations].

4. Zamelyuk, M.I., Oksenchuk, T.V. (2019) Optymizatsiia osvitnoho protsesu dlia studentiv zaochnoi formy orhanizatsii navchannia [Optimization of the educational process for part-time students]. Odesa.

5. Mancall-Bitel, N. How to teach a distracted generation.

6. Taylor, J. Raising Generation Tech: Preparing Your Children for a MediaFueled World.

\section{ВІДОМОСТІ ПРО АВТОРІВ}

ПУШ Олена Анатоліївна - кандидат педагогічних наук, викладач Луцького педагогічного коледжу
} Наукові інтереси: загальна педагогіка та історія
педагогіки

ЯЦИК Тетяна Олегівна - викладач кафедра педагогіки, психології та окремих методик Луцького педагогічного коледжу освіти

Наукові інтереси: теорія і методика професійної

ЗАМЕЛЮК Марія Іванівна - кандидат педагогічних наук, викладач Луцького педагогічного коледжу

Наукові інтереси: теорія і методика професійної освіти

\section{INFORMATION ABOUT THE AUTHOR}

PUSH Olena Anatoliivna - Candidate of Pedagogical Sciences, Lecturer at Lutsk Pedagogical College

Circle of research interests: general pedagogy and history of pedagogy

YATSYK Tetyana Olehivna - Lecturer, Department of Pedagogy, Psychology and Some Methods, Lutsk Pedagogical College

Circle of research interests: theory and methods of vocational education

ZAMELYUK Maria Ivanivna - Candidate of Pedagogical Sciences, teacher Lutsk Pedagogical College

Circle of research interests: theory and methods of vocational education.

Стаття надійшла до редакиї 20.09.2020 p.

УДК 37-042.4:004

DOI: 10.36550/2415-7988-2020-1-191-138-144

RYBALKO Olha Oleksiivna -

$\mathrm{PhD}$ in pedagogic sciences, teacher of mathematics, Pryluky Humanitarian and Pedagogical College named after I. Ya. Franko ORCID:https://orcid.org/0000-0003-2979-9904 e-mail: olgarybalko07@gmail.com MELNYK Oksana Mykolaivna $\mathrm{PhD}$ in pedagogic science, head of the sector of scientific and methodological development of information and digital competence, Institute of educational content modernization ORCID:https://orcid.org/0000-0002-2193-2072 e-mail: ok_melnyk@ukr.net

\title{
MAIN EFFECTS OF INTERACTIVITY IN INTERACTIVE POSTERS FOR PRIMARY SCHOOL STUDENTS
}

Statement and substantiation of the urgency of the problem. Today, in the age of digital society, the role and place of digital technologies and modern technical means in our lives cannot be underestimated. Undoubtedly, there are new requirements for the organization of the educational process in Ukraine, as well as new opportunities to prepare a competitive, creative school leaver of the XXI century through the development and use of new forms, methods, teaching aids and technologies in education. The new generation of children, born in the environment of technical innovations, cannot imagine their life and learning without them.
It is worth noting that less than ten years have passed since computer science began to study from the 2nd grade in Ukrainian schools, and today it is said about the through use of information and communication technologies (ICT) in any lesson, to study any subject and in any class. Gradually, ICT is becoming a new means of learning, an integral part of the educational process in primary school too.

The study of the influence of the use of new types of electronic educational resources (EERs), namely electronic educational game resources (EEGRs) on the educational achievements of primary school students in mathematics, the development of their attention, memory, and thinking have been devoted the works of 
O.M. Melnyk. The researcher identified the features of teaching primary school students using EEGRs [6, p. 131].

The transition of education mostly to mixed and distance forms encouraged primary school teachers to find interesting EERs for students and create their own digital teaching aids that would promote better understanding of learning material, increase applying visual teaching methods, increase the efficiency of the educational process as a whole.

Early school age has its own characteristic psychophysiological features. One of the psychological features of 6-year-olds is that at this age, reliance on visual images greatly facilitates and improves the process of learning, memorizing and remembering educational material, compared to a simple explanation in words. The use of visual aids, created on the basis of modern ICT, not only stimulates cognitive activity, but also forms and develops visual and abstract-logical thinking of primary school students, helps to maintain their attention.

The use of interactive posters in the classroom, as one of the types of EERs for educational purposes, focuses the attention of younger students on the subject of study, encourages them to learn, increases interest and stimulates motivation, which is especially important in the early stages of education. In addition, such teaching aids can create an information and educational environment close to the real life of students born in the digital age. This is very important for elementary students who study more willingly in a familiar environment.

Thus, the transition to digital phase of educational development and new challenges of the time on the one hand, as well as the individual psychological characteristics of 6-year-olds on the other hand prompted the study of interactive posters for primary school students.

Analysis of recent research and publications. The use of interactive and active teaching methods in higher education was studied by O.I. Bashkir [1], N.P. Volkova, M.M.Kozyar, I.Ya.Kotsan, M.M. Yatsishin, Yu.V. Korenga, T.V. Kravchina [4], the use of interactive technologies during the preparation of primary school teachers was the topic of study of K.O. Tkachenko, the use of interactive learning tools and technologies to improve the efficiency of the educational process is considered in the works of I.V. Hevko [3], A.I. Sinko, interactive learning technologies in primary school were the subject of research by L.V. Pyrozhenko and others.

The content of the concept of interactive posters, the method of its creation with the help of the Gloster service and the peculiarities of the organization of the teacher's work were covered by I.Yu. Shakhina [10] and O.I.Ilyina, modeling of electronic interactive posters was studied by S.H. Lytvynova, M.S. Mamuta, O.O. Rybalko [5] and others.

Despite the fact that in scientific discourses there are works devoted to the development of interactive posters, the effects of interactivity of interactive electronic posters developed in the Adobe Flash CS3 environment have not been the subject of scientists' research.

The purpose of the article is to acquaint teachers with the possibilities of using the electronic educational resource "Mathematics for the 1st grade. Interactive posters" (author Rybalko O.A.) in the educational process, the disclosure of its main effects of interactivity.

The research methods. During the study a set of general scientific methods and techniques was used, in particular: methods of systematic and comparative analysis, systematization, generalization of psychological, pedagogical and scientific sources, theoretical analysis and synthesis, generalization, abstraction and concretization, etc.

Statement of the main research material. The need and importance of the transition from passive to active, interactive methods during traditional learning have been repeatedly discussed in scientific and pedagogical debates. However, with the development of technology and the transition to blended and distance learning, the possibility of interactivity, which is often provided by modern software, is becoming an absolute requirement of the time. While the use of interactive exercises has been popular among teachers for decades, interactive posters remain less common.

Interactive posters are especially important for elementary students, who better perceive, remember, and recall learning material that is supported by visual, demonstration tools. These tools of a new type, which provide a high level of involvement of information channels of perception of educational material, are used to illustrate it. Interactive posters are designed to meet the requirements of visualization of education in primary school by including in their content visual aids, applications and schematic drawings. Such tools are used both to identify significant features, connections, phenomena, events, processes, and to form a local image representation of educational material [8].

The researchers note that using of interactive posters allows teachers to enhance the educational and cognitive activities of students through the possibility of using different types of feedback [2].

Compared to ordinary printing posters or ordinary electronic posters, interactive posters are a modern multifunctional learning tool, provide more opportunities for organizing the educational process, and are primarily intended for use in lessons of new material, but they can be used in the process of repetition and consolidation of the studied material [5].

Thus, an interactive poster is an electronic educational resource for educational purposes that can actively and variously respond to user's actions. The interactivity of such a learning tool is provided through the use of various interactive elements: links, navigation buttons, areas of text or digital input, and so on. Such posters contain much more educational material than ordinary posters and provide it in a more visual form.

Interactivity is one of the most important advantages of digital multimedia learning technologies, which are able to take into account the individual characteristics of students and help increase their motivation to learn. 
Interactive posters can be created using various programs and services, including: Microsoft Power Point, Smart Notebook, Adobe Flash, ThingLink, Cacoo, Gloster, Prezi, etc.

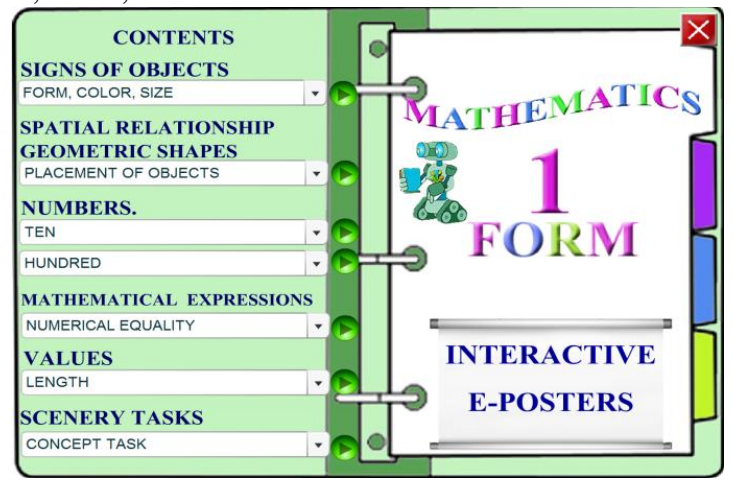

Fig. 1. The home page of the EER "Mathematics for the 1st grade. Interactive posters"

Consider the effects of interactivity, which are present in the EER "Mathematics for the 1st grade. Interactive posters", created by Rybalko O.A. using the Adobe Flash CS 3 system (Fig. 1).

This system is a powerful environment for the development of author's EERs, namely: presentations for lessons, interactive electronic posters, didactic games, test tasks and electronic textbooks.

The built-in graphics tools of the Adobe Flash system provide ample opportunities for the design of EERs, and the programming language Action Script

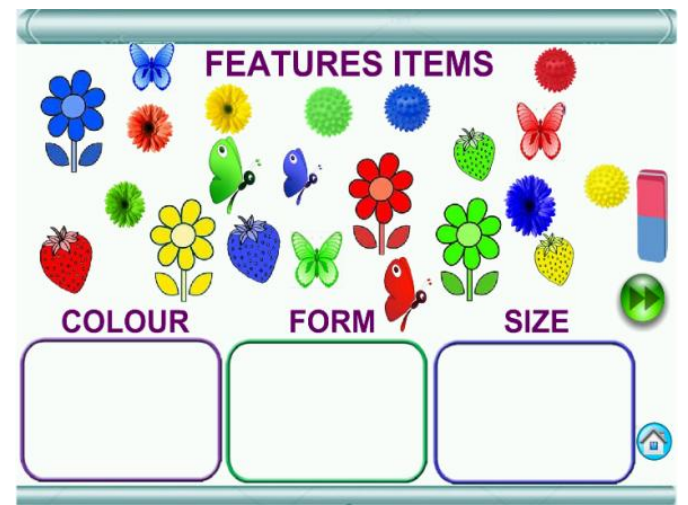

provides the implementation of effective software product management.

A two-level electronic poster model was used in the process of creating this EER.

On the home page of the EER "Mathematics 1st grade. Interactive Posters" a user can choose the topic of any section of the curriculum for the 1 st grade. In the right part you can select electronic pages (e-pages): "Instructions", "Author", "Used resources". This EER consists of separate interactive posters that can be combined for convenience [5].

This EER uses about 10 interactivity effects. Consider some of them in more detail.

The interactivity effect 1 . The posibility to move objects on an electronc page. Interactive electronic visual tools have replaced paper ones [7]. A teacher has the opportunity not only to illustrate the relevant actions, but together with students to check the effectiveness of mastering this material. Especially in the case when the use of visual tools is not reduced to a simple illustration in order to make the learning process more accessible and easy to understand, but becomes an organic part of students' cognitive activity, a means of forming and developing not only visual but also abstract and logical thinking.

Consider, for example, the use of visual tools in interactive electronic posters on the example of studying the topic "Objects' features" (Fig. 2).

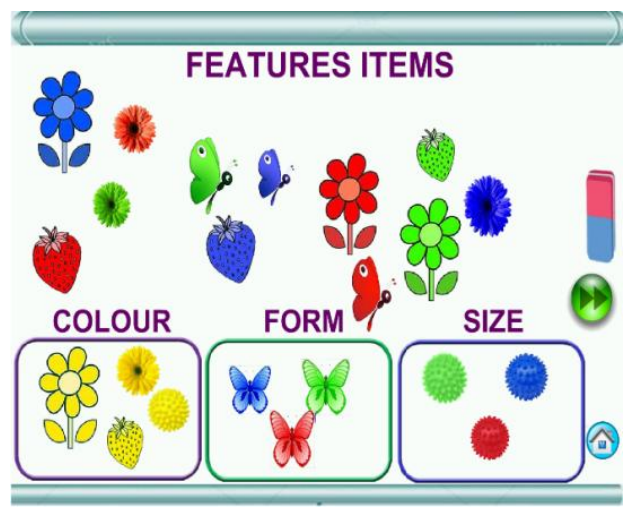

Fig. 2. Demonstration of the possibility to move objects on the e-page.

Using this interactive poster, both a teacher and students have an opportunity to move objects, unite them in groups according to the colours, sizes, forms. This is only one example. In general, a primary school teacher needs a lot of visual aids, so the described type of interactivity is often used in interactive posters created for primary school.

For user's usability (fig. 2) the buttons for clearing of the corresponding pages of the used images are programmed on such e-pages. For example, clicking on the image of the blue and red eraser (Fig. 2), a user goes to the e-page, which was at the beginning of the work. In this way, he gets an opportunity to start over.

The interactivity effect 2 . The possibility of closing and opening records with the corresponding pictures. To do this, there are the buttons serving for opening or clothing the records with the corresponding pictures (the images of a closed and opened book in this EER).

When a teacher clicks the left button of a mouse on the images of the closed books (located at the bottom of e-pages), the records become invisible, and when he clicks on the images of the open books (located at the top of e-pages), all records become visible. Clicking on the images themselves, which close the records, helps gradually open them. The buttons that open all records at the same time are scheduled only for convenience. Imagine a situation where all records are closed. A teacher needs to open some tasks, placed in a certain column. You can do this by gradual clicking on the images that close them. But such work takes much time. That's why simultaneous closing and opening the records can be done with the help of planned buttons. The 
greatest effect in using of these electronic posters can be observed at the stage of consolidation of the studied

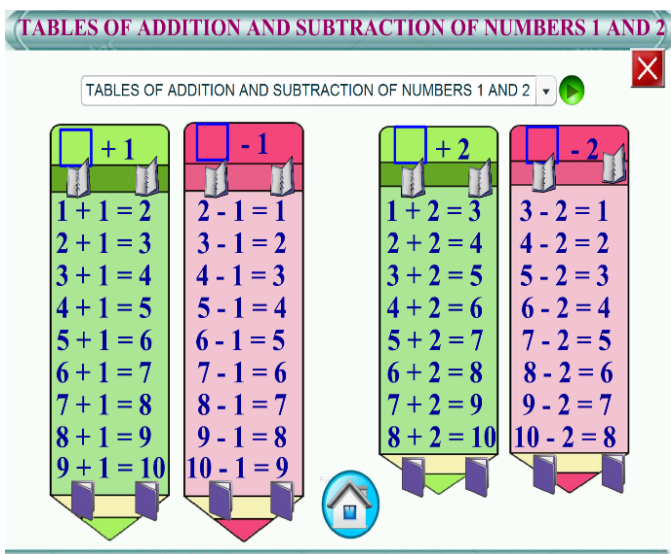

Fig. 3. Demonstration of the pos

This is a very important feature of interactive posters. It can be used both at the stage of studying new material and at the stage of consolidating the studied material. Compared to paper posters, the use of interactive posters has a number of advantages. Students do not see the answers to the questions asked by a teacher. This encourages them to think, to make certain conclusions [9].

This effect of interactivity can be used in interactive posters created not only for primary school students, but also for middle and high school students, students of higher educational institutions. For example, they can be used when you need to check knowledge of formulas, definitions, etc.

The interactivity effect 3. The possibility to record relevant information on an e-page). An interactive abacus is showed in fig. 4. This type of visualization is

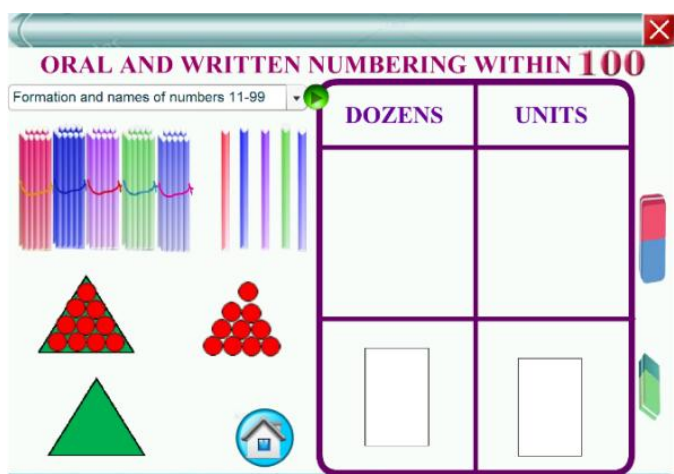

Fig. 4. Demonstration of the possibility to move visual images and record relevant information.

For convenience, some buttons are programmed for cleaning text fields from unnecessary information (used records). To do this, simply click the left mouse button on the image of the green eraser (at the bottom of an epage). To return the visual tool on its place, you need to click on the image of the blue and red eraser, which is located on the right side of an e-page, just above the green eraser.

The interactivity effect 4. Using animation in electronic posters. We consider the example of the material. A teacher opens the corresponding task gradually, and students give answers (Fig. 3).

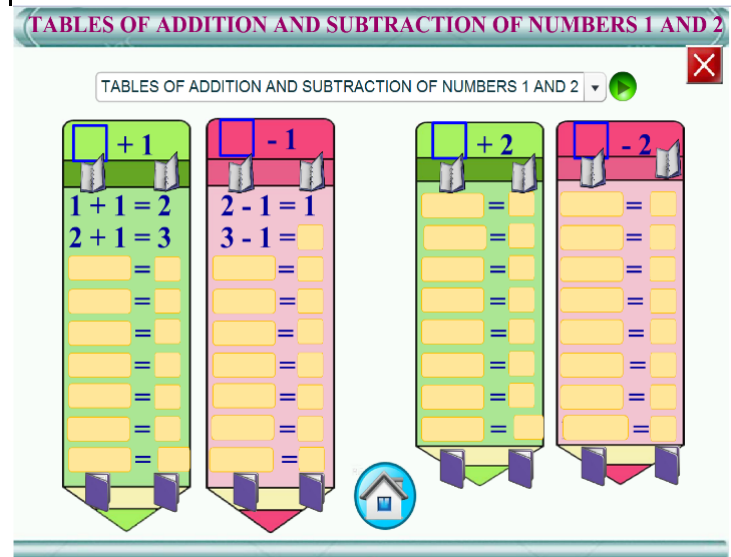

ossibility to close and open records.

used in the process of studying the first grade students of oral and written numbering within a hundred. It has no difference from ordinary abacus. A teacher conducts the work in the same way as some decades ago.

All counting material can be moved along an e-page and placed in the necessary place. All visual tools are placed at the top of an e-page. The numbers are noted in the special text fields.

An experienced teacher involves students in work. He demonstrates, and students enter the appropriate records from the keyboard. A teacher can write the corresponding two-digital number at the bottom of the electronic abacus, and students present the corresponding visual tools in the upper part. In this way, younger students have the opportunity to train themselves and offer tasks to each other.

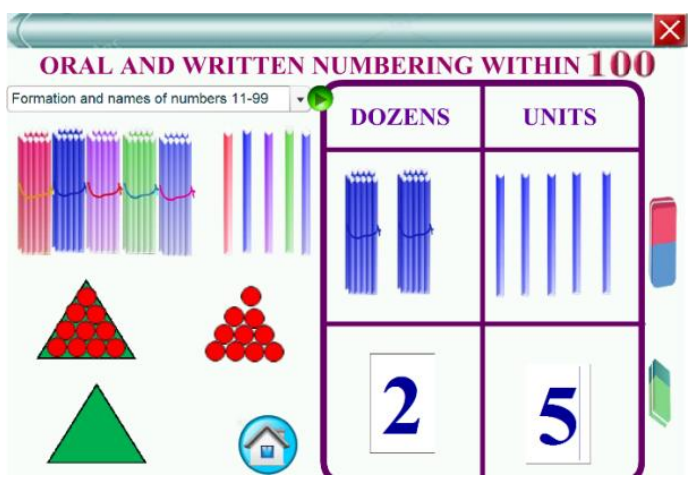

interactive poster created to study the topic "Time". There are two clocks on this page. The yellow (sand color) clock works as usual. And the green one is designed to get acquainted with an hour, a unit of time. After students come to the conclusion that the time is measured in hours, the teacher opens the corresponding record. And the second conclusion that an hour passes, when the long hand goes around the circle once, and the short one moves to the next number, younger students do with the help of visual tools (Fig. 5). The green clock and 
the buttons below it have been created for this purpose. When a teacher clicks the left mouse button on the button located on the right below the clock image, the long hand

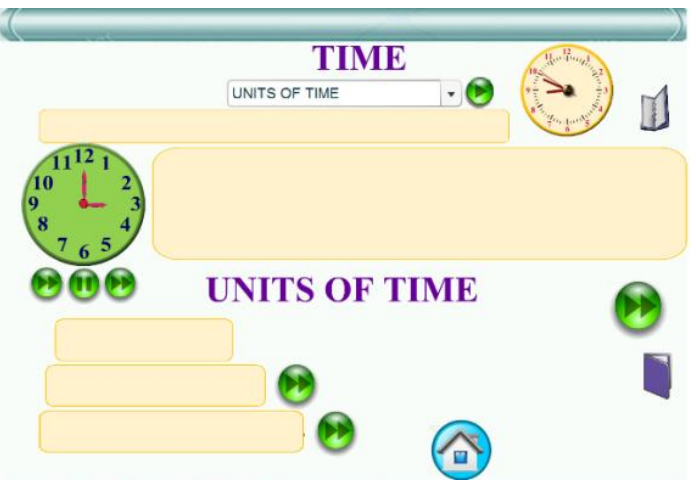

starts moving. The middle button stops the movement of the long hand and the green button on the left allows you to continue moving the long hand.

Fig. 5. Demonstration of the possibility to move visual images and record relevant information.

This kind of interaction can be used with the help of additional buttons for checking (for example, to define the mass). First, a teacher introduces the unit of mass the kilogram. And then in turn he puts on the scales the appropriate weights, checking with a button from the

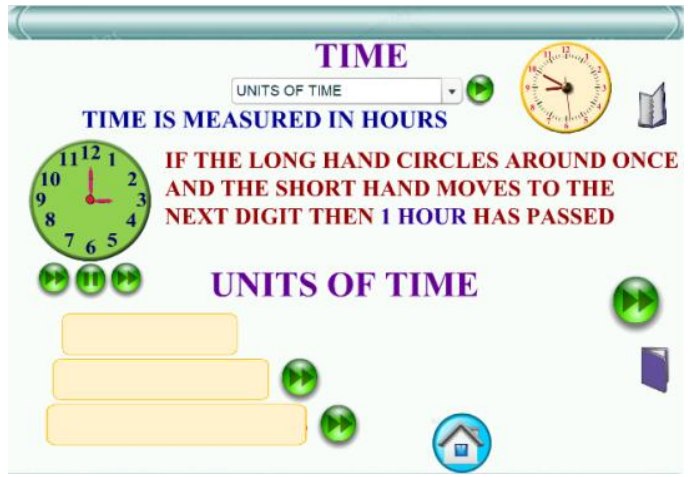

images of a magnifying glass, whether the scales are in balance each time. After the students have determined the weight of the placed objects, together with the teacher they write down the answer. Undoubtedly, it is very convenient to use this type of interactivity (Fig. 6).

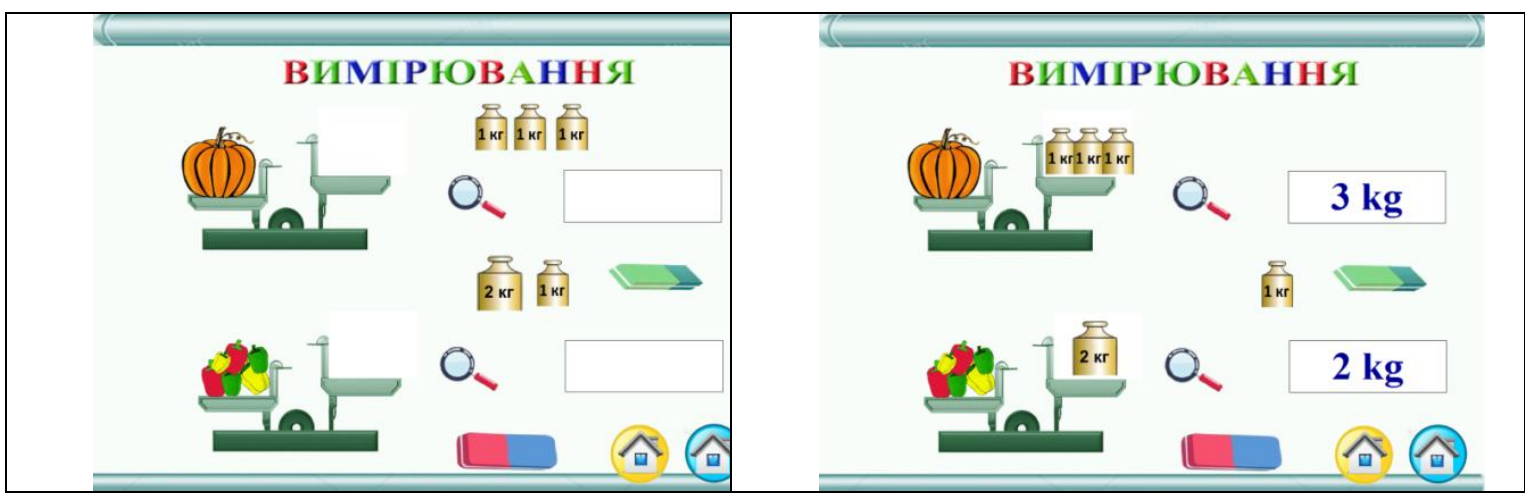

Fig. 6. Demonstration of animation using the buttons to check.

The interactivity effect 5. Using the buttons to display necessary information. You can write relevant information on an e-page, schedule buttons and images to open or close the relevant records at right time for a teacher. But some information takes up a lot of space on an e-page. Therefore it is possible to place certain messages with a condition that they will appear only when it is necessary (fig. 7). In the process of clicking the button with the question mark, the desired record will appear. If the left button of a mouse is clicked on this image (writing on a yellow sheet), it disappears.
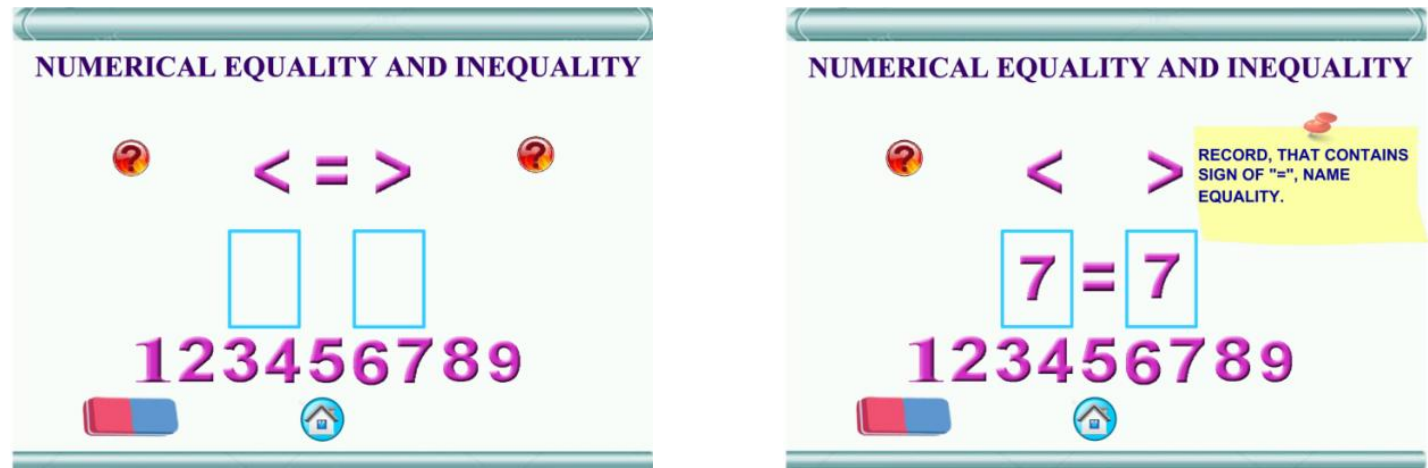

Fig. 7. Example of using buttons to display relevant information.

This effect of interactivity, used on this e-page, allows you to free up space, focus younger students' attention on the formation of numerical equalities and inequalities. 
Conclusions. Interactivity is one of the most important advantages of electronic posters comparing to other learning tools. Interactivity allows you to control the provision of certain information. Like using textbooks, using of electronic posters can enrich teaching strategies only when a teacher not only provides certain information, but also guides, supports and helps students in learning process.

The use of various interactivity effects in interactive posters allows you to more quickly manage the students' activities in the process of acquiring new knowledge, which is an undeniable advantage over traditional forms of learning.

Due to the different interactive effects interactive posters are more visually attractive than graphic or ordinary e-posters. Their usage helps support the emotional level of students. It also gives the opportunity to add teaching materials that are given in the textbooks.

Correct usage of interactive posters at lessons assists to form clear contents concepts, to develop logical thinking and language. It is useful in considering and analyzing the certain phenomena to come to generalizations that are applied in further practice.

Such suggested methodic for using interactive eposters in pre-school educational establishments and those with inclusive training is considered to be perspective. The given methodic can be used for visualization of educational process not only at the lessons of mathematics, but also at the lessons of other subjects that are taught in primary school. Besides, some effects of interactivity are to be investigated and used in the secondary school.

Such suggested methodic is considered to be perspective for using interactive e-posters in pre-school educational establishments and those with inclusive training. This technique can be used to illustrate the learning process not only in mathematics, but also in other subjects studied in primary school. In addition, some interactivity effects that can be used in middle and high school are to be studied.

\section{СПИСОК ДЖЕРЕЛ}

1. Башкір O.I. Активні й інтерактивні методи навчання у вищій школі. Збірник наукових праць «Педагогіка та психологія». 2018. Вип. 60. С. 33-44.

2. Бобровская Л.Н., Данільчук Е.В., Кулікова Н.Ю. Інтерактивні електронні освітні ресурси як засіб підвищення якості освіти на початковому етапі загальної освіти. Міжнародна науково-практична конференція. Тирасполь: ПГІРО, 2015. С. 152-157.

3. Гевко I.B. Використання інтерактивних технологій в освіті. Педагогічні науки. 2015. Вип. 139. С. $53-60$.

4. Кравчина Т.В. Види інтерактивних методів навчання англійської мови для студентів технічних спеціальностей. Відкрите освітнс електронне середовище сучасного університету, 2018. № 5. С. 140-145.

5. Литвинова С., Мамута М., Рибалко О. Моделювання електронних інтерактивних плакатів. Фізико-математичне виховання. 2018. № 4 (18), С. 96-100. DOI: 10.31110/2413-1571-2018-017-3-015.
6. Мельник О.М. Проектування електронних освітніх ресурсів з математики для учнів початкових класів : дис. ... канд. пед. наук : 13.00.10 / Інститут інформаційних технологій та засобів навчання. Київ, 2017. 295 с.

7. Pushkareva T., Rybalko O. Designing of the electronic educational resources by the future teacher for the math lessons at elementary school. Education Science and Psychology, 2017. № 4(46), C. 53-58. URL: http://gesj.internet-

academy.org.ge/ru/list_artic_ru.php?b_sec=edu\&issue=201712 (дата звернення 05.09.2020)

8. Рибалко О.О. Проектування електронних освітніх ресурсів навчання математики в початковій школі 3 використанням системи Adobe Flash : дис. ... канд. пед. наук : 13.00 .10 / Інститут інформаційних технологій та засобів навчання. Київ, 2017. 259 с.

9. Рибалко О.О. Створення та застосування інтерактивних електронних таблиць на уроках математики в початкових класах. Інформаційні технології та засоби навчання. 2016. № 53 (3). C. 38-48. URL: https://core.ac.uk/download/pdf/

77241434.pdf (дата звернення 05.09.2020)

10. Шахіна I.Ю., Ільїна О.І. Інтерактивні плакати в освітній діяльності. Проблеми та перспективи формування національної гуманітарно-технічної еліти: зб. наук. праць Харків : НТУ «ХПІ», 2015. С. 403-412.

\section{REFERENCES}

1. Bashkir, O.I. (2018) Aktyvni y interaktyvni metody navchannia $u$ vyshchii shkoli. [Active and interactive teaching methods in higher education].

2. Bobrovskaya, L.N., Danilchuk, E.V. \& Kulikova, N.Yu. (2015). Interaktyvni elektronni osvitni resursy yak zasib pidvyshchennia yakosti osvity na pochatkovomu etapi zahalnoi osvity. [Interactive electronic educational resources as a means of improving the quality of education at the initial stage of general education]. Tiraspol.

3. Hevko, I.V. (2018) Vykorystannia interaktyvnykh tekhnolohii $v$ osviti. [Use of interactive technologies in education].

4. Kravchyna, T.V. (2018) Vydy interaktyvnykh metodiv navchannia anhliiskoi movy dlia studentiv tekhnichnykh spetsialnostei. [Types of interactive methods of teaching English for technical students.].

5. Lytvynova, S., Mamuta, M., \& Rybalko, O. (2018). Modeliuvannia elektronnykh interaktyvnykh plakativ. [Modeling of Electronic Interactive Posters]

6. Melnyk, O.M. (2017) Proektuvannia elektronnykh osvitnikh resursiv $z$ matematyky dlia uchniv pochatkovykh klasiv [Design of electronic educational resources in mathematics for primary school students].

7. Pushkareva, T. \& Rybalko, O. (2017) Designing of the electronic educational resources by the future teacher for the math lessons at elementary school.

8. Rybalko, O.O. (2017). Proektuvannia elektronnykh osvitnikh resursiv navchannia matematyky $v$ pochatkovii shkoli z vykorystanniam systemy Adobe Flash [Designing of electronic educational resources for teaching mathematics in elementary school using the Adobe Flash system].

9. Rybalko, O.O. (2016) Stvorennia ta zastosuvannia interaktyvnykh elektronnykh tablyts na urokakh matematyky $v$ pochatkovykh klasakh. [The creation and use of interactive spreadsheets in mathematics in primary school].

10. Shakhina, I.Yu. (2015) Interaktyvni plakaty v osvitnii diialnosti. [Interactive posters in educational activities]. 


\begin{tabular}{l}
\hline \multicolumn{4}{c}{ ВІДОМОСТІ ПРО АВТОРІВ } \\
РИБАЛКО Ольга Олексіївна - кандидат \\
педагогічних наук, викладач математики Прилуцького \\
гуманітарно-педагогічного коледжа ім. І. Я. Франка. \\
Наукові інтереси: інформаційно-комунікаційні \\
технології в освіті, викладання математики, методика \\
навчання математиці, учні початкової школи. \\
МЕльНИК Оксана Миколаївна - кандидат \\
педагогічних наук, завідувач сектору науково-методичного \\
забезпечення інформаційно-цифрової компетентності \\
Інституту модернізації змісту освіти. \\
Наукові інтереси: інформаційно-комунікаційні \\
технології в освіті, електронні освітні ресурси, \\
використання новітніх технологій в освіті, інформаційно- \\
цифрова компетентність.
\end{tabular}

DOI: 10.36550/2415-7988-2020-1-191-144-147

\section{INFORMATION ABOUT THE AUTHOR}

RYBALKO Olha Oleksiivna - $\mathrm{PhD}$ in pedagogic sciences, teacher of mathematics in Pryluky Humanitarian and Pedagogical College named after I.Ya. Franko.

Circle of scientific interests: information and communication technologies in education, teaching mathematics, methods of teaching mathematics, primary school students.

MELNYK Oksana Mykolaivna - $\mathrm{PhD}$ in pedagogic sciences, head of the sector of scientific and methodological development of information and digital competence in Institute of educational content modernization.

Circle of scientific interests: information and communication technologies in education, electronic educational resources, use of the latest technologies in education, information and digital competence.

Стаття надійшла до редакиії 20.09.2020 p.
СЕЛИЩЕВА Ірина Анатоліївна кандидат педагогічних наук, старший викладач кафедри всесвітньої історії Криворізького державного педагогічного університету ORCID:https://orcid.org/0000-0002-4841-6449 e-mail: irina.selischeva2016@gmail.com

\section{СОЩАЛЬНО-ПОЛІТИЧНІ ТА КУЛЬТУРНО-ОСВІТНІ ПЕРЕДУМОВИ СТАНОВЛЕННЯ ВІТЧИЗНЯНОЇ СИСТЕМИ ІСТОРИЧНОЇ ОСВІТИ (1917 - СЕРЕДИНА 20-Х РР. ХХ СТ.)}

Постановка та обгрунтування актуальності проблеми. Аналіз розвитку історичної освіти в Україні радянського періоду, ii ролі та місця в національній історії й освіті залишається актуальною проблемою попри те, що іiі окремі аспекти неодноразово висвітлювалися у науковій літературі. Дослідження особливостей розвитку історичної освіти надає можливість переосмислити, надати об'єктивну оцінку і зрозуміти підгрунтя, на якому побудована сучасна система історичної освіти. Тому, доцільно детальніше розглянути розвиток історичної освіти в Україні у період від 1917 р. до середини 20-х років ХX ст. (доба відродження української національної державності та перші роки радянської влади).

Аналіз останніх досліджень i публікацій. Питання розвитку історичної освіти в Україні початку XX ст. у своїх наукових студіях порушувала низка науковців-істориків, які не залишали поза увагою педагогічний аспект. Цінний фактологічний матеріал щодо навчання історії окресленого періоду містять наукові розвідки дослідників В. Арешонкова, О. Пометун, В. Мисана, С. Слободяна, І. Смагіна, Т. Теремецької (шкільна історична освіта), Н. Вєнцевої, К. Ушмаєвої (виша історична освіта) та ін.

Мета статті - проаналізувати розвиток історичної освіти в Україні у період від 1917 р. до середини 20-х рр. ХХ ст., який охоплює час, що пов'язують в історії України з добою відродження національної державності, та перші роки радянської влади.
Методи дослідження. Задля всебічного висвітлення проблеми дослідження i виявлення передумов становлення сучасної системи історичної освіти було використано теоретичні методи: вивчення, аналіз та узагальнення наукової літератури.

Виклад основного матеріалу дослідження. Упродовж 1917-1920 pp. (доба відродження української національної державності) українські уряди (Центральної Ради, Гетьманату, Директорії) спрямовували зусилля передусім на захист національних інтересів. Важливим завданням у цьому напрямі було створення та розбудова системи національної освіти, фундаторами якої були українські науковці В. Антонович, Д. Багалій, М. Грушевський, І. Стешенко та ін. Зокрема, у резолюції II Всеукраїнського учительського з'їду в Києві (1917р.) зазначається: «Позаяк національна школа $є$ не тільки ідеальним гаслом, [...], у шкільній роботі мусить мати місце національна творчість словесна, музична, мистецька, в згоді 3 індивідуальними нахилами дітей, широке ознайомлення з рідним краєм, його історією ...» $[2$, c. 65]. Як результат такої освітньої політики, відкривалися українські гімназії (за часів Центральної Ради їх кількість досягла 50, а за часів Гетьманату - 100), видавалися шкільні підручники, необхідні для українізації освіти, був розроблений план єдиної школи в Україні («Проект Сдиної школи на Вкраїні» впроваджено в 1919 р.) тощо. Серед предметів обов'язкового вивчення пропонується 